\title{
Ten years of research on history of science (physics): A bibliometric analysis
}

\author{
${ }^{*}$ E A Yanuarti ${ }^{1}$, N Suprapto ${ }^{2}$ \\ 1,2Department of Physics, Faculty of Mathematics and Natural Science, Universitas Negeri Surabaya, Surabaya 60231, \\ Indonesia
}

\begin{tabular}{l} 
Article Info \\
\hline Article history: \\
Received February 15, 2021 \\
Revised March 28, 2021 \\
Accepted April 10, 2021 \\
Available Online April 27, 2021 \\
\hline
\end{tabular}

Keywords:

History of science History of physics Bibliometric analysis Scopus

\begin{abstract}
History of science (HoS), nature of science (NoS), and philosophy of science (PoS) are three fundamental concepts in science and physics education. Specifically, this research explored ten years of research of HoS based on the Scopus database through a bibliometric study. The findings indicated some points: the number of articles in 2011-2020 tended to be stable. Sears dominated research on HoS as the top author. Meanwhile, Isis, Science \& Education, and Nature were the top sources of research. The USA was a dominant country in researching HoS, followed by UK and Germany. Paper from Tewksbury et al. in the Journal of Bioscience has gained the most citations. Researchers on the world produced four clusters: historian along centuries, HoS in relating to philosophy and nature of science, HoS in connecting with timeline each country along years, and HoS in relating to university and relevant project. The researchers have also offered an advanced research model related to HoS.
\end{abstract}

\section{INTRODUCTION}

The history of science is a study of the development of science, including both the natural and social sciences (the history of the arts and humanities). In simple terms, science can be defined as the study of the nature of science (Suprapto, Mubarok, Adam, 2019). There are many types of science, ranging from medical science (medical), Earth science, social science, physics, mathematics, psychology, law, chemistry, astronomy, language, history, and other scientific fields that fall into the corridors of human reasoning (Forinash \& Rumsey, 2000). History of science (physics) deals with understanding the concept of epistemology, ontology, and axiology, the branch of philosophy (Suprapto, 2021).

The development of science, of course, does not just happen but requires a very long time and process, even since ancient times (Efendi et al., 2020). So, what about the history of science from time to time?

1. Science in early humans

2. Science is much more advanced in the before century $(B C)$ era

3. Science continues to develop in the Middle Ages

4. The development of science today

\section{Science in the future}

Nowadays, science has developed into knowledge that has become a necessity to be taught in every school and educational institution in the world (Forinash \& Rumsey, 2000). Starting in the early 1900s, Albert Einstein has discovered significant theories that are very influential for the world. From then on, the development of science became increasingly unstoppable. Science Daily notes that Einstein's theory of relativity is one of the grand theories that has survived 
until now. Previously there was the Law of Gravity which was initiated by a great scientist named Isaac Newton. Understanding Einstein's and Newton's theories are not easy and require a very detailed study (Whitaker, 1979).

We who live in modern times are always accompanied by many discoveries and technologies previously initiated by world scientists and academics. The internet, telecommunications, medical, modern transportation, nuclear resources, electrical devices, modern astronomy, and all things related to science can be enjoyed at this time through a long journey.

What will happen in the world of science in the future? I do not know; no one knows. However, it is predicted that science will be more advanced many times than it is today. Perhaps, in the future, there will be interplanetary travel available to the public. Robotic technology may have replaced important human tasks, which are now beginning to appear. For now, the dream of living on another planet may sound like nonsense, but in the future, it may happen. The reason is, in 2030, humans through NASA and other space agencies have started planning to send astronauts to Mars.

Learning the history of science or physics is essential because we can learn various knowledge and sciences (Abd-El-Khalick \& Lederman, 2000; Stuewer, 1998). From the history of physics, we can study the successes that have been achieved by previous scientists, how they achieved their discoveries, how they overcome obstacles, and other things (Demirci, 2016). Aspects learned in studying history do not escape the discussion of the $5 \mathrm{~W}$ and $1 \mathrm{H}$ (Suprapto, \& Dwikoranto, 2019).

What, Who, Where, When, Why, How.

What: What happened?

Who: Who was the perpetrator of the incident?

Where: Where did the incident occur?

When: When did the event occur?

Why: Why did these events occur?

How: How did the incident occur?

Associated with the discussion in the course of the history of physics, we know that wherever and whenever, physics will experience developments in any aspect when the conditions of society and the existing government are also supportive and in a stable state (Baldwin, 2018; Grinina, I. R., \& Ilizarov, S. S. (2020). The discussion that is studied related to the contribution of a society or nation to the development of physics, the development of physics content from time to time, and a brief biography of scientists who are essential contributors to the development of physics are some of the main aspects of the history of physics that are important for students to know and are essential to developing. Taking for example, in a brief history of physics and religion (Edwin, 1999), previous research focused on gravity and Qur'an (Amalia \& Suliyanah, 2020); relativity of Einstein (Celina \& Suprapto, 2020). After searching through the Scopus database, there is no study about the history of science and history of physics that utilized bibliometric study; therefore, this research is pioneering research on this topic. Thus, this study focused on researching the history of science through bibliometric analysis to know the research trend of the history of science in the last ten years. Studying the history of science is essential and fulfils the knowledge needs, especially in journals related to the philosophy of science and education (Suprapto, Ku, Cheng, \& Prahani, 2020).

\section{RESEARCH METHOD}

This study utilized a bibliometric study by using Scopus database. The data was collected in February 2021. Originally, the authors found 4,778 document results by using key words in searching metadata: "TITLE (history AND of AND science)".

Then, through the limitation process of the time-spent of publication (2011-2020) resulted 1,978 documents, with the following key words: "TITLE (history AND of 
AND science ) AND ( LIMIT-TO ( PUBYEAR, 2020 ) OR LIMIT-

TO ( PUBYEAR, 2019) OR LIMIT-TO ( PUBYEAR, 2018 ) OR LIMIT-

TO (PUBYEAR, 2017 ) OR LIMIT-TO ( PUBYEAR, 2016 ) OR LIMIT-

TO (PUBYEAR, 2015 ) OR LIMIT-TO (PUBYEAR, 2014 ) OR LIMIT-

TO ( PUBYEAR, 2013 ) OR LIMIT-TO ( PUBYEAR, 2012 ) OR LIMIT-

TO ( PUBYEAR, 2011) )

Two kinds of metadata were saved into .Csv and .ris for further data analysis. Microsoft Excel and VOSviewer (van Eck \& Waltman, 2020) were used in visualizing from raw data into Table, graph, and map.

\section{RESULTS AND DISCUSSION}

Figure 1 depicts the number of documents on the history of science in the last ten years in the Scopus database. The number of articles in general increased less sharply and tended to be stable. This result indicates that research in this field tends to be constant every year, with a minimum number of 144 for the last ten years.

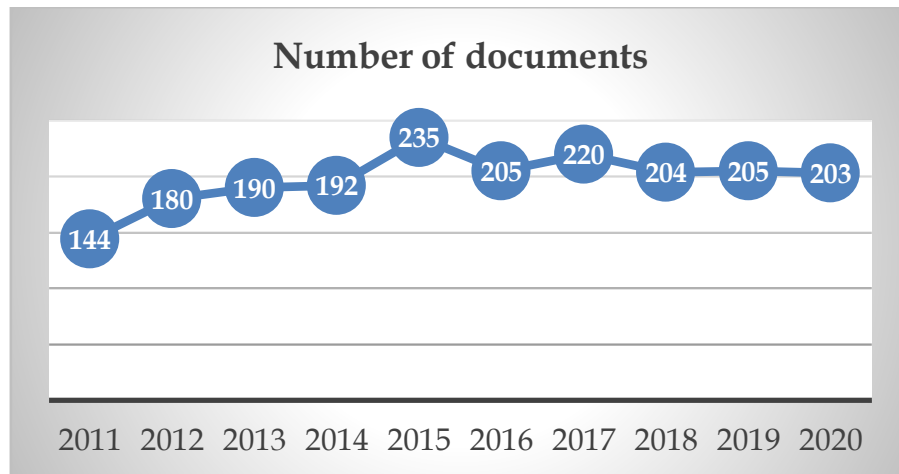

Figure 1. The development of research on history of science in Scopus database

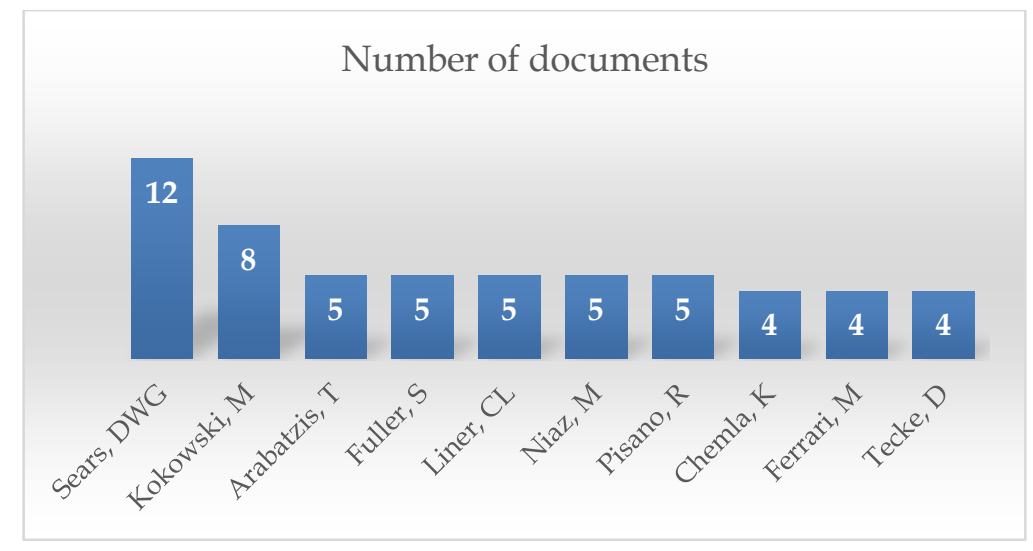

Figure 2. Top authors of history of science in the last ten years in Scopus

Research on the history of science was dominated by Sears (12 documents) as the top author and followed by Kokowski (8 documents), as indicated in Figure 2 . The most top authors are from the USA. 
Table 1. Top sources of research on history of science

\begin{tabular}{lc}
\hline \multicolumn{1}{c}{ Sources } & Number of documents \\
\hline Isis $(\mathrm{J})$ & 54 \\
Science \& Education $(\mathrm{J})$ & 37 \\
Nature $(\mathrm{J})$ & 19 \\
Boston Studies in The Philosophy \& History of Science (J) & 18 \\
Centaurus (J) & 18 \\
Int. Handbook of Res. in History Philosophy \& Science Teaching (B) & 18 \\
Studies in History \& Philosophy of Science Part A (J) & 18 \\
History of Science (J) & 16 \\
Int. Encyclopedia of The Social Behavioral Sciences; $2^{\text {nd }}$ Ed. (B) & 14 \\
Meteoritics and Planetary Science $(J)$ & 13 \\
\hline
\end{tabular}

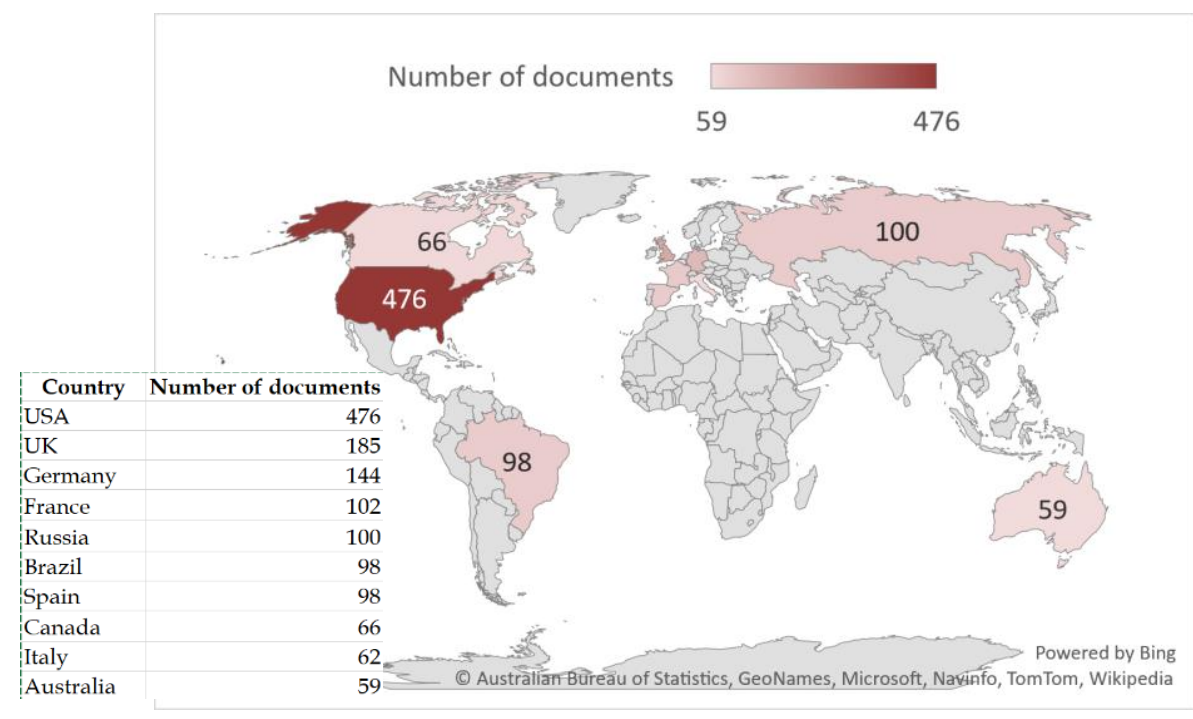

Figure 3. The distribution of documents on history of science across countries

Meanwhile, Isis, Science \& Education, and Nature were the top sources of research on the history of science. The complete ten top sources of the history of science are listed in Table 1. USA was the dominant country in researching the history of science, followed by the UK, Germany, France, and Russia with documents more than 100. With full documents, 50 to 100 were Brazil, Spain, Canada, Italy, and Australia as the remaining top countries contribute to science history (Figure 3). While the USA was dominant in the history of science documents, the institutions were dominated by CNRS Centre National de la Recherche Scientifique, France, Russian Academy of Sciences, Russia, and University of Cambridge, the UK in the last ten years. Meanwhile, the rest institutions could be seen in Table 2.

Table 3 lists the top five citations in 2011-2020 of history of science articles. All five documents are journal articles. Paper from Tewksbury et al. (2014) in Journal of Bioscience was gained the most citations (158), followed by Bullot \& Reber (2013) in Behavioral and Brain Sciences and Mayer, Wallenius, \& Varga (2013) in Chemical Reviews. 
Table 2. Top institutions of research on history of science in the world

\begin{tabular}{lc}
\hline \multicolumn{1}{c}{ Institution } & Number of documents \\
\hline CNRS Centre National de la Recherche Scientifique, France & 28 \\
Russian Academy of Sciences, Russia & 24 \\
University of Cambridge, UK & 22 \\
Max Planck Institute for the History of Science, Germany & 20 \\
Harvard University, USA & 17 \\
Universidade de Lisboa, Portugal & 17 \\
Cornell University & 15 \\
Universidade de Sao Paulo - USP, Brazil & 15 \\
NASA Ames Research Center & 13 \\
The University of Manchester & 12 \\
\hline
\end{tabular}

Table 3. Top citations of research on history of science (2011-2020)

\begin{tabular}{|c|c|c|c|}
\hline Title & Author(s) & & $\begin{array}{l}\text { Number } \\
\text { of } \\
\text { citations }\end{array}$ \\
\hline $\begin{array}{l}\text { Natural history's place in science } \\
\text { and society }\end{array}$ & $\begin{array}{l}\text { Tewksbury et } \\
\text { al. }(2014)\end{array}$ & BioScience,_64(4), 300-310 & 158 \\
\hline $\begin{array}{l}\text { The artful mind meets art history: } \\
\text { Toward a psycho-historical } \\
\text { framework for the science of art } \\
\text { appreciation }\end{array}$ & $\begin{array}{l}\text { Bullot \& Reber } \\
\text { (2013) }\end{array}$ & $\begin{array}{l}\text { Behavioral and Brain } \\
\text { Sciences,_36(2), 123-137 }\end{array}$ & 135 \\
\hline $\begin{array}{l}\text { Nuclear forensic science: } \\
\text { Correlating measurable material } \\
\text { parameters to the history of nuclear } \\
\text { material }\end{array}$ & $\begin{array}{l}\text { Mayer, } \\
\text { Wallenius, \& } \\
\text { Varga (2013) }\end{array}$ & $\begin{array}{l}\text { Chemical Reviews, } \\
113(2), 884-900\end{array}$ & 116 \\
\hline $\begin{array}{l}\text { A History of Animal Welfare } \\
\text { Science }\end{array}$ & Broom (2011) & $\begin{array}{l}\text { Acta Biotheoretica, 59(2), } \\
\text { 121-137 }\end{array}$ & 116 \\
\hline $\begin{array}{l}\text { The history of the science and } \\
\text { technology of electrospinning from } \\
1600 \text { to } 1995\end{array}$ & $\begin{array}{l}\text { Tucker et al. } \\
\text { (2012) }\end{array}$ & $\begin{array}{l}\text { Journal of Engineered } \\
\text { Fibers and Fabrics,_7(3), } \\
63-73\end{array}$ & 110 \\
\hline
\end{tabular}

Among those 1978 papers related to history of science research in the Scopus database, then the researchers visualized the research trends on this topic assisted with VoSViewer software. This effort is useful for finding the novelty of the research on this domain. Figure 4 indicates the whole picture research on history of science. Researchers on the world produced four clusters indicated with red, blue, green, and yellow). The first cluster (red color) was historian along centuries. The second cluster (blue) was history of science in relating to philosophy and nature of science (see Suprapto, 2021). The third cluster (green) was history of science in connecting with time line each country along years. The last cluster (yellow) indicated history of science in relating to university and relevant project. 


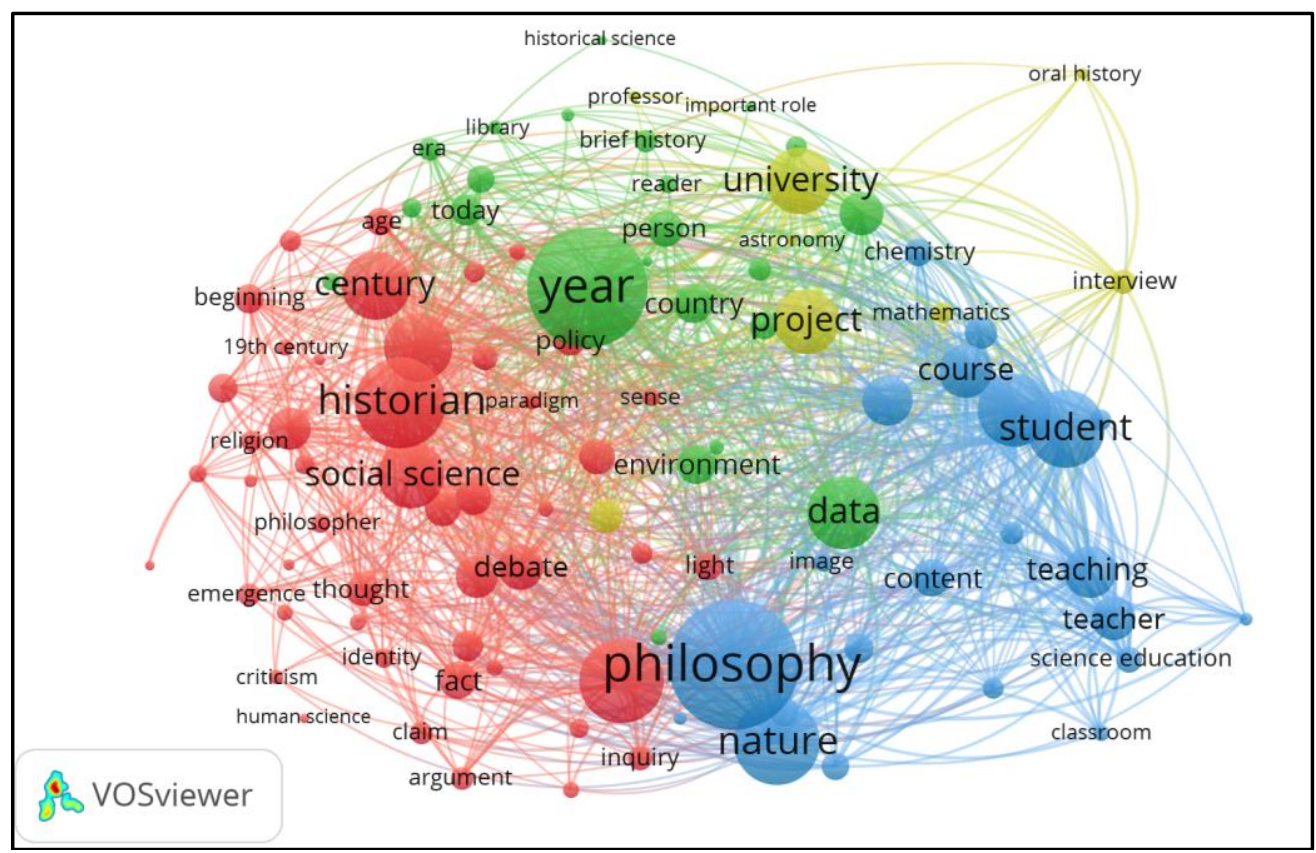

Figure 4. The network visualization map of history of science
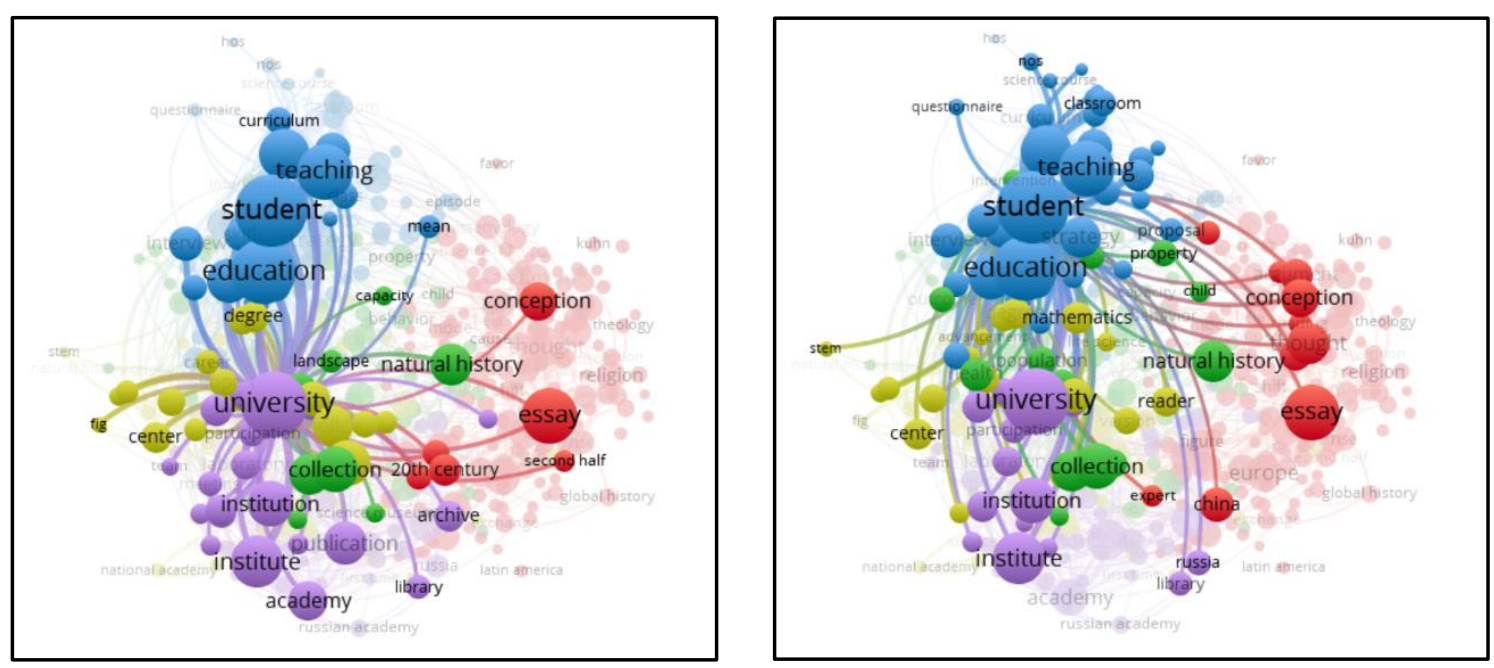

Figure 5. Student and university as the central variable of research in history of science

If we broke down into the specific connection among variables to capture the trend and novelty of researching the history of science (Figure 5-7), we found some findings. First, if the variable focused on student or university (Figure 5), we found many occurrences variables: education, teaching, classroom, academy, institution, conception, curriculum, collection, natural history, thought, and essay. It means it is up-and-coming research related to the history of science concerning these educational variables. It is the novelty offered for research on the history of science in the world of education, either high school or college. This finding was inlined with the study of Demirci (2016) who studied teaching the history of science in physics classrooms. Previously, Abd-El-Khalick and Lederman (2000) have also researched on the influence of history of science courses on students' views of nature of science. Study of the implementation of Socratic dialogue at History of Physics course was also supported this findings (Efendi et al., 2020). 


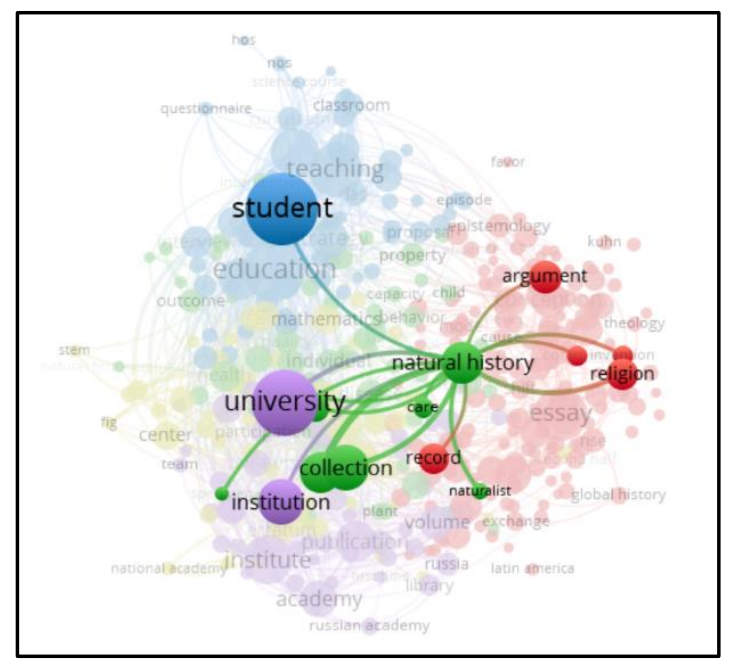

Figure 6. Natural history as the central variable of research in history of science

The study of natural history is also one of the novelties offered for historical research, including the history of physics. Here, we can relate our research to student and university. Moreover, alternative research on the history of science should be addressed to argumentation (Efendi et al., 2020) and religion (Amalia \& Suliyanah, 2020; Celina \& Suprapto, 2020; Edwin, 1999). Therefore, research on science and religion is developed, physics and religion, history and scientific argumentation.

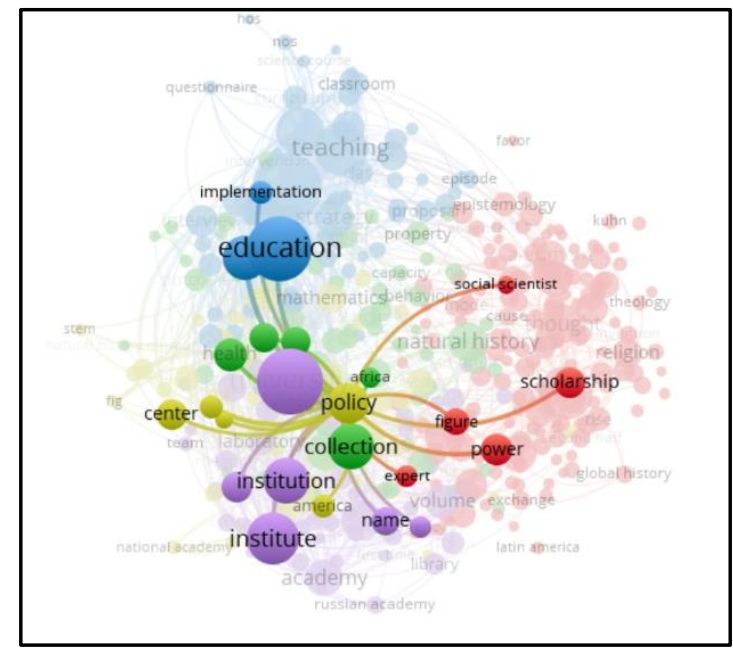

Figure 7. Policy as the central variable of research in history of science

Figure 7 indicates policy as the central of research on history of science. It means that research related to policy in the history of science has the potential to be developed. Figure 8 showed the top researcher and its cluster in researching the history of science (Efendi et al., 2020; Forinash \& Rumsey, 2000). It was clear that, Sears, Kokoswki, Pisano, Chemla, Arabatzis, Niaz, Simon, Greene, Liner were dominant author and co-authorships. All group of authors are from countries in Figure 3 above. 


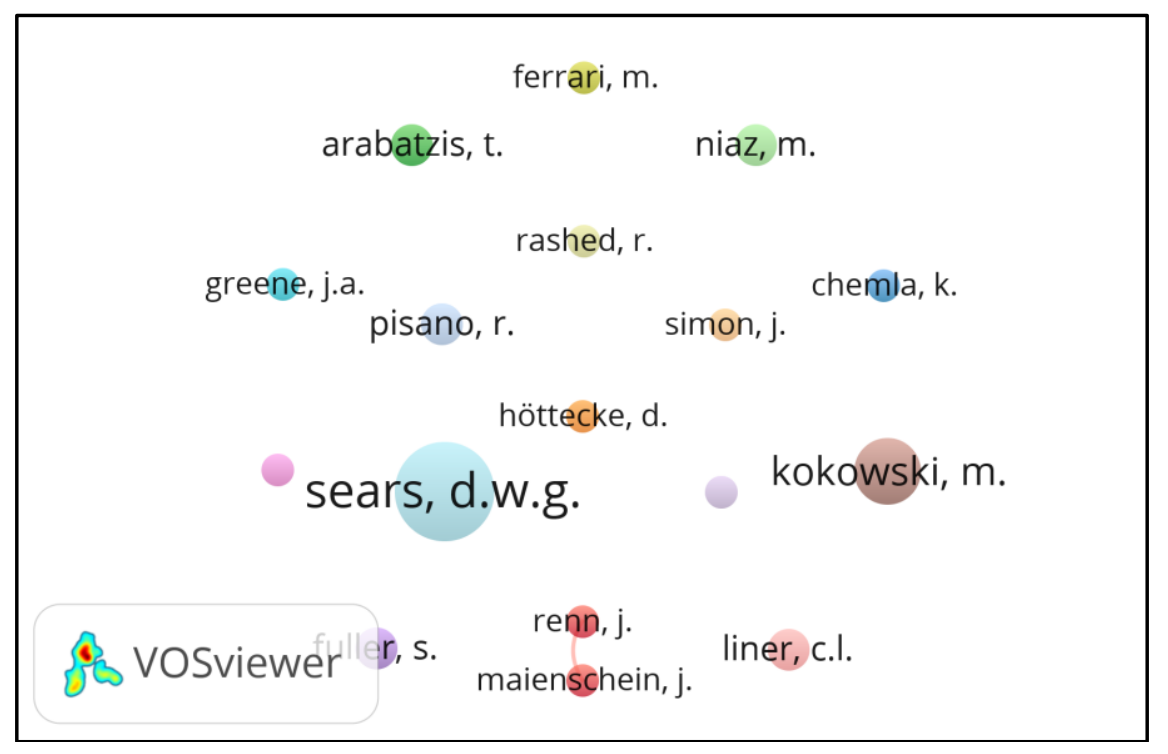

Figure 8. Top researcher and its cluster in researching the history of science

Researchers offer an advanced research model related to the history of science through Figure 9. Accordingly, the most occurring keyword is science education. In the first cluster (green), the keywords are science education concerning classroom, curriculum, scientific literacy, and questionnaire. Then, the second cluster (red), with the most occurrence, is religion linkages with science history, natural philosophy, the scientific revolution, and modern science. The next cluster (blue), a philosopher, is linked with Thomas Kuhn - an initiator of the scientific revolution, research method, basic science, and science course. The yellow cluster, scientific inquiry, cognitive science, and new perspective of the history of science relate to each other. The last study of the history of science should consider the domain of STEM (purple).

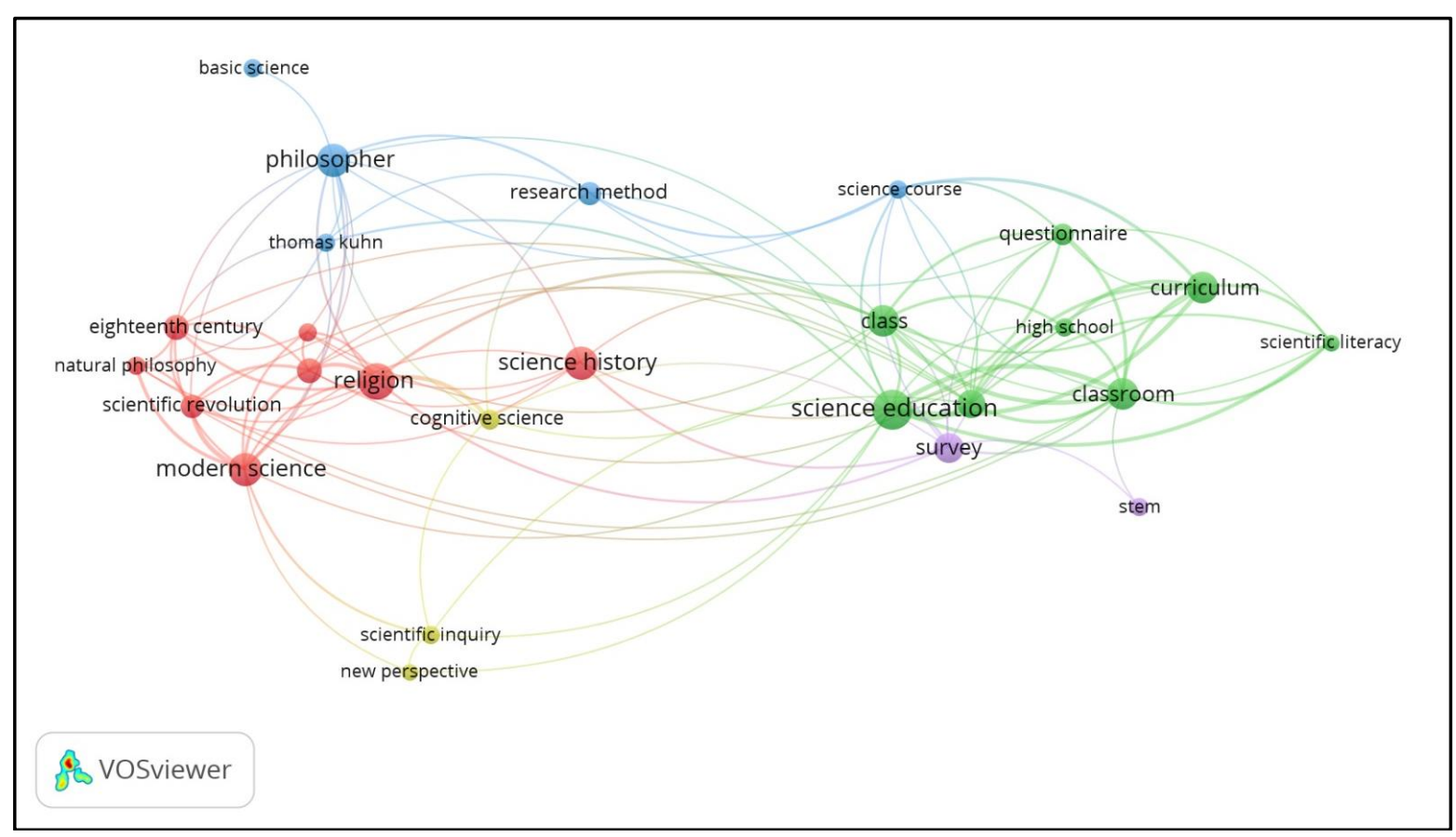

Figure 9. An advanced research model related to history of science 


\section{CONCLUSION}

This study shows that the number of articles in 2011-2020 increased less sharply and became stable. Research on the history of science was dominated by Sears as the top author and followed by Kokowski. The most top authors are from the USA. Meanwhile, Isis, Science \& Education, and Nature were the top sources of research on the history of science. The USA was a dominant country in researching the history of science, followed by the UK and Germany.

In contrast, the institutions were dominated by CNRS Centre National de la Recherche Scientifique, France, Russian Academy of Sciences, Russia, and University of Cambridge, the UK, in the last ten years. Paper from Tewksbury et al in the Journal of Bioscience has gained the most citations. Researchers on the world produced four clusters: historian along centuries, history of science in relating to philosophy and nature of science, history of science in connecting with timeline each country along years, and history of science in relating to university and relevant project. The authors have also offered an advanced research model related to the history of science.

\section{REFERENCES}

Abd-El-Khalick, F., \& Lederman, N. G. (2000). The influence of history of science courses on students' views of nature of science. Journal of Research in Science Teaching, 37(10), 1057-1095.

Amalia, K., \& Suliyanah, S. (2020). Muslim students' understanding about interconnection of gravity in science and the Qur'an. Studies in Philosophy of Science and Education, 1(3), 127-136. https://doi.org/10.46627/sipose.v1i3.54

Baldwin, M. (2018). The history of physics, in 4000 manuscripts. DOI:10.1063/PT.6.4.20180221a. https:// physicstoday.scitation.org/do/10.1063/PT.6.4.20180221a/full/

Broom, D. M. (2011). A History of Animal Welfare Science. Acta Biotheoretica, 59(2), 121-137.

Bullot, N. J., \& Reber, R. (2013). The artful mind meets art history: Toward a psycho-historical framework for the science of art appreciation. Behavioral and Brain Sciences, 36(2), 123-137.

Demirci, N. (2016). Teaching the history of science in physics classrooms - the story of the neutrino. Physics Education, 51, 043003.

Celina, F. M., \& Suprapto, N. (2020). Study of relativity theory of Einstein: The story of Ashabul Kahf and Isra' Mi'raj. Studies in Philosophy of Science and Education, 1(3), 118-126. https://doi.org/10.46627/sipose.v1i3.48

Edwin, C. (1999). A brief history of physics and religion. Physics World, 12(12), 69.

Efendi, M. Y., Cheng, T.-H., Sa'diyah, E. H., Wulandari, D., Qosyim, A., \& Suprapto, N. (2020). Study of the implementation of Socratic dialogue at History of Physics course. Studies in Philosophy of Science and Education, 1(1), 7-20. https://doi.org/10.46627/sipose.v1i1.7

Forinash, K., \& Rumsey, W.D. (2000). A first course in the history and philosophy of science. European Journal of Physics, 21, 427.

Grinina, I. R., \& Ilizarov, S. S. (2020). The objectives of studying the history of science in the USSR: the situation in 1952. IOP Conf. Ser.: Earth Environ. Sci. 579, 012161.

Mayer, K., Wallenius, M., \& Varga, Z. (2013). Nuclear forensic science: Correlating measurable material parameters to the history of nuclear material. Chemical Reviews, 113(2), 884-900.

Stuewer, R. H. (1998). History and Physics. Science $\mathcal{E}$ Education, 7, 13-30. https://doi.org/10.1023/A:1008688309198

Suprapto, N. (2021). Physics education students' understanding of the concept of epistemology, ontology, and axiology. Journal of Physics: Conference Series, 1747(1), 012015.

Suprapto, N., \& Dwikoranto. (2019). Sejarah Fisika. Penerbit : JDS.

Suprapto, N., Ku, C.-H., Cheng, T.-H., \& Prahani, B. K. (2020). Editorial: The launch of Studies in Philosophy of Science and Education (SiPoSE). Studies in Philosophy of Science and Education, 1(1), 1-3. https://doi.org/10.46627/sipose.v1i1.3 
Suprapto, N., Mubarok, H., Adam, A.S. (2019). Understanding the nature of science through a content analysis of dynamic fluid: Voices of pre-service physics teachers. Journal of Physics: Conference Series, 1417(1), 012073.

Tewksbury, J. T., Anderson, J. G. T., Bakker, J. D., Billo, T. J., Dunwiddie, P. W., ...\& Wheeler, T. A. (2014). Natural history's place in science and society. BioScience, 64(4), 300-310.

Tucker, N., Stanger, J. J., Staiger, M. P., Razzaq, H., \& Hofman, K. (2012). The history of the science and technology of electrospinning from 1600 to 1995. Journal of Engineered Fibers and Fabrics, 7(3), 63-73.

van Eck, N.J., \& Waltman, L. (2020). VOSviewer manual. Retrieved from https://www.vosviewer.com/documentation/Manual_VOSviewer_1.6.16.pdf

Whitaker, M. A. B. (1979). History and quasi-history in physics education. Physics Education, 14, 108.

\footnotetext{
Author (s):

* Eva Ayu Yanuarti (Corresponding Author)

Department of Physics, Faculty of Mathematics and Natural Science,

Universitas Negeri Surabaya,

Jl. Ketintang, Surabaya 60231, Indonesia

Email: eva.17030184075@mhs.unesa.ac.id

Nadi Suprapto

Department of Physics, Faculty of Mathematics and Natural Science,

Universitas Negeri Surabaya,

Jl. Ketintang, Surabaya 60231, Indonesia

Email: nadisuprapto@unesa.ac.id
} 